\title{
Mathematical problem-solving ability: The impact of mathematics learning videos on an E-learning platform
}

\author{
Aufa Salsabila ${ }^{1}$, Trisna Roy Pradipta ${ }^{1}$ \\ ${ }^{1}$ Universitas Muhammadiyah Prof. Dr. Hamka \\ $\llbracket$ aufasalsabila679@gmail.com*
}

Article Information

Submitted March 10, 2021

Revised March 30, 2021

Accepted April 22, 2021

Keywords

Problem Solving Abilities;

Tutorial video

\begin{abstract}
This study aimed to determine the effect of instructional videos on an elearning platform toward students' mathematical problem solving ability. This research employed the quantitative aproach and experimental research design. This study utilized a test instrument to determine students' mathematical problem solving abilities. Furthermore, a t-test was performed on the data that had fulfilled the prerequisite testings: the normality test and the homogeneity test. The results indicated that there was an effect of mathematics learning videos on the e-learning platform on students' mathematical problem solving abilities. Students who watched the instructional videos had better mathematical problem solving abilities than students who did not watch the instructional videos.
\end{abstract}

\section{INTRODUCTION}

Education plays an important role in developing the quality and potential of human beings' daily life (Hanifah et al 2019). Education also has broad activities dimensions and variables (Syazali 2015). Psychologically, education cannot be separated from the teaching and learning process of guiding students to achieve predetermined goals (Syazali 2015). Formal education in Indonesia involves mathematics as a subject that must be studied in the classroom.

Mathematics is a general science that underlies the development of technology and science. It also plays an important role in several disciplines to improve human thinking (Assidiqi 2015; Indriani and Imanuel 2018). Mathematics is an important science that can help humans in solving everyday problems (Ariawan 2017). In schools, mathematics can promote students' problem-solving abilities (Samsiyah and Rudyanto 2015; Mawaddah and Anisah 2015). Poor problem-solving abilities will affect other mathematical abilities (Ariawan 2017; Waskitoningtyas 2020).

Problem solving ability is essesntial for those who study and implement it in mathematics (Ruseffendi 2006). Mathematical problem solving consists of four steps: understanding the problem, planning the problem, solving the problem according to the planning, and checking all performed steps (Hidayat and Sariningsih 2018). Each stage supports each other in mathematical problem solving, therefore, students are required to master the four stages. Students' poor mathematical problem solving ability negatively affect their learning outcomes (Awaliyah 2015), Therefore, it is necessary to make an effort to overcome it. E-learning platform is one of the solutions that can fix this problem.

During the COVID-19 pandemic, teachers are required to use E-learning platform as a medium in the learning process. Technology services, such as telephone, audio, video, and computers support the implementation of E-Learning (Kusmana 2017). In its application, E- 
Learning also requires an appealing design so that the learning process can be more effective (Hanum 2013; Chandrawati 2010; Elyas 2018). It is important to sustain the learning objectives and the development of E-Learning. One of the media that can be implemented in an E-learning is instructional video. Instructional videos are media capable of highlightning images and sounds (Pamungkas et al. 2018). Teachers can easily spread the developed learning videos into social networks such as Google Drive, Facebook, Blog, YouTube, and many others (Astuti and Febrian 2019). Some research results show that students are more interested in learning using video rather than texts and still images (Purwanti 2015; Purwanto and Rizki 2015; Nuritha and Tsurayya 2021). Therefore, instructional videos are expected to improve students' mathematical problem solving abilities.

Several previous studies have also looked at the impact of instructional videos on learning outcomes (Hamdanillah et al 2017; Jatmiko et al 2017; Yunita and Wijayanti 2017), concept understanding, and learning motivation (Iwantara et al. 2014). The novelty of this research lies in the use of instructional video as a media to promote students' mathematical problem solving abilities in a distance learning class setting. The instructional videos used in this research have been declared feasible by previous researchers (Chidayat 2021). Therefore, this research continues the previously done research.

\section{METHODS}

The researchers employed the quantitative approach to look for differences between the the experimental group (instructional videos on e-learning platform) and the control group (conventional learning) (Fitri and Haryanti 2020). This research used the quasi-experimental design of the non-equivalent posttest-only control group design. The population consisted of 576 SMP Tinta Emas Indonesia students. The samples consisted of 63 students of class 8.2 (as the experimental class) and class 8.4 (as the control class). The sampling technique used was the cluster random sampling because the samples were homogeneous or relatively homogeneous (no superior class) (Lestari et al 2015).

The mathematical problem solving test instrument had been tested for its validity, discrimination index, level of difficulty, and reliability. Furthermore, the hypothetical test employed in this research was the t-test. The following figure illustrate the flow of data collection up to the t-test:

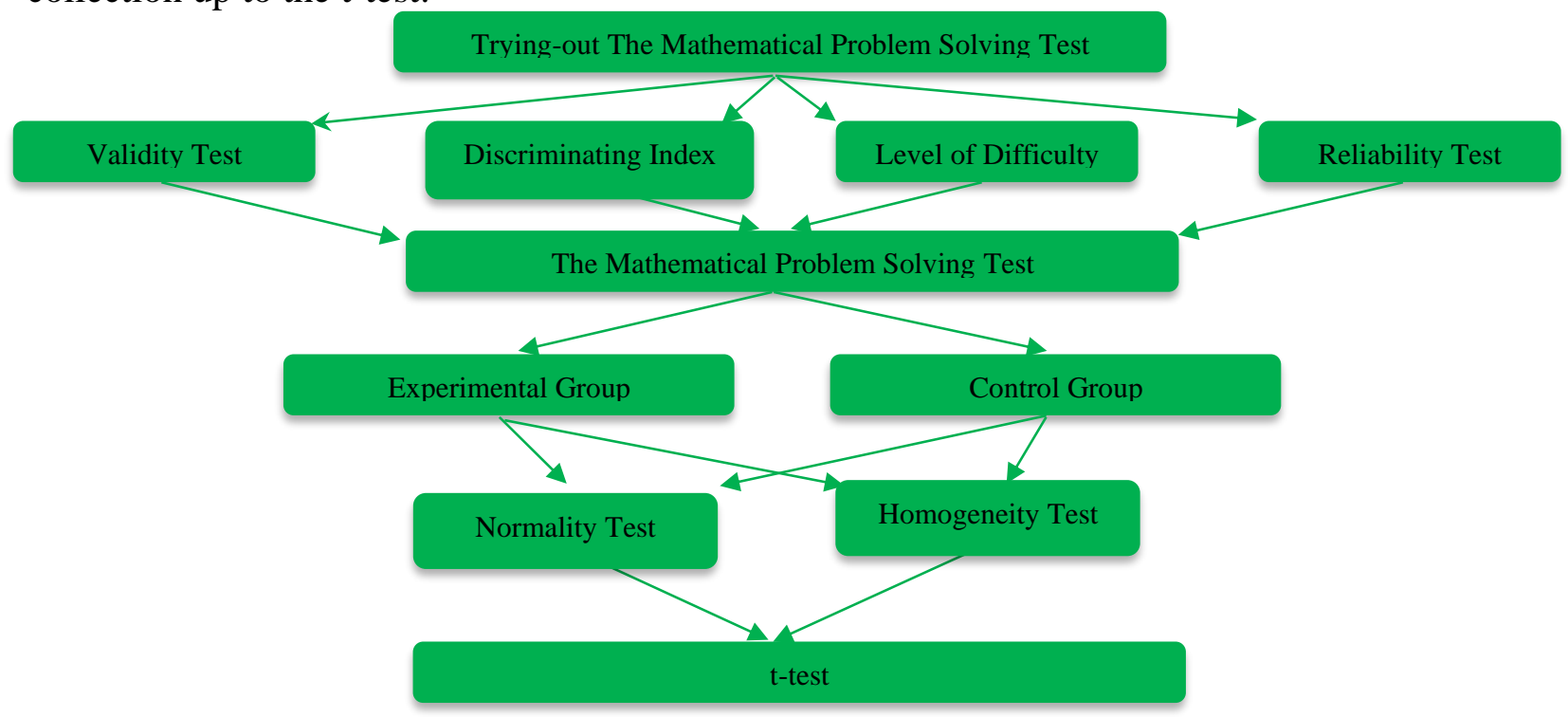

Figure 1. The Flow of Research 


\section{RESULTS AND DISCUSSION}

Students' mathematical problem solving abilities that had been collected were measured for their central tendency (mean, median, and mode) and the size of the group variance (range, variance, and standard deviation). The summary can be seen in table 1 .

Table 1. Data Description of Mathematical Problem Solving Ability

\begin{tabular}{lcclll}
\hline \multirow{2}{*}{ Classes } & \multicolumn{2}{c}{ Central Tendency } & \multicolumn{3}{l}{ Group Variance } \\
\cline { 2 - 6 } & $\bar{x}$ & Mo & Me & s & R \\
\hline Experimental & 83,187 & 90 & 90 & 614,466 & 44 \\
\hline Control & 58,193 & 64 & 64 & 637,340 & 77 \\
\hline
\end{tabular}

The previously analyzed data were then analyzed for their normality. The normality test results were used to determine thether the data were normally distributed or not. The summary can be seen in Table 2 .

Table 2. The Result of Normality Test

\begin{tabular}{cll}
\hline \multirow{2}{*}{ Liliefors Test } & \multicolumn{2}{c}{ Groups } \\
\cline { 2 - 3 } & \multicolumn{3}{c}{ Experimental } & \multicolumn{1}{c}{ Control } \\
\hline $\mathrm{L}_{\text {observed }}$ & 0.089 & 0.144 \\
\hline $\mathrm{L}_{\text {critical }}$ & 0.157 & 0.159 \\
\hline Conclusion & $\mathrm{L}_{\text {observed }}<\mathrm{L}_{\text {critical }}$ (Normal) & $\mathrm{L}_{\text {observed }}<\mathrm{L}_{\text {critical }}$ (Normal) \\
\hline
\end{tabular}

Table 2 shows that the data of each group were normally distributed. Thus, the homogeneity test can be performed. The following table summarizes the homogeneity test:

Table 3. The Result of Homogeneity Test

\begin{tabular}{llllll}
\hline Groups & $\mathbf{k}$ & $\mathbf{F}_{\text {observed }}$ & $\mathbf{F}_{\text {critical }}$ & Decision & Conclusion \\
\hline Experiment and Control & 2 & 0.485 & 1.84 & $\mathrm{H}_{0}$ is accepted & Homogeneous \\
\hline
\end{tabular}

The test result indicated that the experimental and control groups had homogeneous variances. Furthermore, the hypothesis was tested using the t-test. The test summary can be seen in Table 4.

Table 4. The Result of t-Test

\begin{tabular}{lll}
\hline $\mathbf{t}_{\text {observed }}$ & $\mathbf{t}_{\text {critical }}$ & Decision \\
\hline 7.26 & 1.67 & $\mathbf{H}_{0}$ is rejected \\
\hline
\end{tabular}

Table 4 shows that $\mathrm{H}_{0}$ is rejected, which means that there was an effect of mathematics learning videos on E-learning toward students' mathematical problem solving abilities. Also,Table 1 reveals that the average mathematical problem solving ability of the experimental class students was 83.187 which is higher than the control class (58.193). Therefore, the mathematical problem solving abilities of students who learned through instructional videos were better than students who learned through conventional learning.

\section{Discussion}

The experimental class consisted of 32 students and the control class consisted of 31 students. Class 8.2 (experimental class) learned through instructional videos while class 8.4 (control class) did not apply the instructional videos. In this class, the researchers (as teachers) tried to explore students' mathematical problem solving abilities by posing questions or problems. The learning in class 8.2 composed of four meetings. Three meetings were utilized as the learning activities through WhatsApp Group. The researchers provided teaching materials and links to the instructional videos. The test was given in the last one meeting. 
In the experimental class, the teacher uploaded learning materials through WhatsApp group. The materials were links to the instructional video and teaching materials. The instructional videos discuss the cubes and blocks materials accompanied by sample questions and discussion. In the control class, the teacher only provided teaching material through the WhatsApp Group, meanwhile, students hold discussions with each other via the WhatsApp group. If students did not understand the material, they can ask questions via personal WhatsApp chat or the WhatsApp group chat.

During the teaching and learning process, students who learned through the instructional videos were more active. Most of the mathematical problems can be solved quickly and accurately. Learning videos that can be utilized repeatedly are very efficient in the learning process. The results of this study complement several previous studies which state that videos provide positive impacts in the learning process (Busyaeri et al 2016; Iwantara et al. 2014; Yunita and Wijayanti 2017).

\section{CONCLUSIONS}

Based on the analysis, it can be concluded that instructional videos on E-learning platform positively affected students' mathematical problem solving abilities. Students who learned through instructional videos had better mathematical problem solving abilities than students who learned through conventional learning.

The use of instructional videos during the COVID-19 pandemic is very effective o foster students' mathematical problem solving abilities. Therefore, further researchers are expected to investigate the effects of instructional videos on other abilities.

\section{AUTHOR CONTRIBUTIONS STATEMENT}

AS worked as the main drafter in this research. data collection and instrument design assisted by TRP.

\section{REFERENCES}

Ariawan, R. 2017. Hubungan kemampuan pemecahan masalah matematis dengan kemampuan komunikasi matematis siswa. Jurnal THEOREMS (The Original Research of Mathematics) 1(2), 82-91.

Assidiqi, H. 2015. Membentuk karakter peserta didik melalui model pembelajaran search, solve, create, and share. Math Didactic: Jurnal Pendidikan Matematika 1(1), 45-55.

Astuti, P., and Febrian F. 2019. Diseminasi online multimedia pembelajaran matematika yang dikembangkan menggunakan videoscribe. Jurnal Anugerah 1(1), 19-24.

Awaliyah, G. 2015. "Pengaruh kemampuan pemecahan masalah terhadap hasil belajar matematika siswa kelas V SD se-gugus Ki Hajar Dewantara kecamatan Tegal Timur Kota Tegal." PhD Thesis, Universitas Negeri Semarang.

Busyaeri, A., Udin, T., and Zaenudin, A. 2016. Pengaruh penggunaan video pembelajaran terhadap peningkatan hasil belajar mapel IPA di MIN Kroya Cirebon. Al Ibtida: Jurnal Pendidikan Guru MI 3(1), 116-137.

Chandrawati, S. R . 2010. Pemamfaatan e-learning dalam pembelajaran. Jurnal Cakrawala Kependidikan 8(2). 
Chidayat, R. 2021. Analisis video presentasi linier materi persamaan linier satu variabel pada channel youtube, teman belajar online, Le Gurules, Mathsyairozi." in Seminar Nasional Pendidikan dan Ilmu Matematika (SENANDIKA) 2020.

Elyas, A. H. 2018. Penggunaan model pembelajaran e-learning dalam meningkatkan kualitas pembelajaran. Warta Dharmawangsa (56).

Fitri, Agus Zaenul, and Nik Haryanti. 2020. Kuantitatif, Kualitatif, Mixed Method, and Research and Development. Madani Media.

Hamdanillah, N., Harjono. A., and Susilawati, S. 2017. Pengaruh model pembelajaran advance organizer menggunakan video pembelajaran terhadap hasil belajar fisika peserta didik kelas XI. Jurnal Pendidikan Fisika Dan Teknologi 3(2), 119-27.

Hanifah, H. Supriadi, N., and Widyastuti, R. 2019. Pengaruh model pembelajaran e-learning berbantuan media pembelajaran edmodo terhadap kemampuan pemecahan masalah matematis peserta didik. NUMERICAL: Jurnal Matematika Dan Pendidikan Matematika $3(1): 31-42$.

Hanum, N. S. 2013. Keefetifan e-learning sebagai media pembelajaran (studi evaluasi model pembelajaran e-learning SMK telkom sandhy putra Purwokerto). Jurnal Pendidikan Vokasi 3(1), 90-102.

Hidayat, W., and Sariningsih. R. 2018. Kemampuan pemecahan masalah matematis dan adversity quotient siswa SMP melalui pembelajaran open ended. JNPM (Jurnal Nasional Pendidikan Matematika) 2(1), 109-18.

Indriani, M. N., \& Imanuel, I. (2018, February). Pembelajaran matematika realistik dalam permainan edukasi berbasis keunggulan lokal untuk membangun komunikasi matematis. In PRISMA, Prosiding Seminar Nasional Matematika (Vol. 1, pp. 256-262).

Iwantara, I. W., Sadia, W. I., and Suma, K. 2014. Pengaruh penggunaan media video youtube dalam pembelajaran IPA terhadap motivasi belajar dan pemahaman konsep siswa. Jurnal Pendidikan Dan Pembelajaran IPA Indonesia 4(1), 1-13.

Jatmiko, P. D., Wijayantin, A., and Susilaningsih, S. 2017. Pengaruh pemanfaatan video pembelajaran terhadap hasil belajar IPA kelas IV sekolah dasar. Edcomtech Jurnal Kajian Teknologi Pendidikan 1(2), 153-56.

Kusmana, A. 2017. E-Learning dalam pembelajaran. Lentera Pendidikan: Jurnal Ilmu Tarbiyah Dan Keguruan 14(1), 35-51.

Lestari, Karunia Eka, and Mohammad Ridwan Yudhanegara. 2015. Penelitian pendidikan matematika. PT Refika Aditama.

Mawaddah, S., and Anisah, H. 2015. Kemampuan pemecahan masalah matematis siswa pada pembelajaran matematika dengan menggunakan model pembelajaran generatif (generative learning) di SMP. EDU-MAT: Jurnal Pendidikan Matematika 3(2), 166-175.

Nuritha, C., and Tsurayya, A. 2021. Pengembangan video pembelajaran berbantuan geogebra untuk meningkatkan kemandirian belajar siswa. Jurnal Cendekia: Jurnal Pendidikan Matematika 5(1), 48-64. 
Pamungkas, A. S., Ihsanudin, I., Novaliyosi, N., and Yandari, I. A. V. 2018. Video pembelajaran berbasis sparkol videoscribe: Inovasi pada perkuliahan sejarah matematika. Prima: Jurnal Pendidikan Matematika 2(2), 127-35.

Purwanti, B. 2015. Pengembangan media video pembelajaran matematika dengan model assure. Jurnal Kebijakan Dan Pengembangan Pendidikan 3(1), 42-47.

Purwanto, Y., and Rizki, S. 2015. Pengembangan bahan ajar berbasis kontekstual pada materi himpunan berbantu video pembelajaran. AKSIOMA: Jurnal Program Studi Pendidikan Matematika 4(1), 67-77.

Ruseffendi, E. T. 2006. "Pengantar kepada membantu guru mengembangkan kompetensinya dalam pengajaran matematika untuk meningkatkan CBSA.” Bandung: Tarsito.

Samsiyah, N., and Rudyanto, H. E. 2015. Kemampuan berpikir kreatif dalam memecahkan masalah matetatika open-ended ditinjau dari tingkat kemampuan matematika siswa sekolah dasar. PEDAGOGIA: Jurnal Pendidikan 4(1), 23-33.

Syazali, M. (2015). Pengaruh model pembelajaran creative problem solving berbantuan media maple 11 terhadap kemampuan pemecahan masalah matematis. Al-Jabar: Jurnal Pendidikan Matematika, 6(1), 91-98.

Waskitoningtyas, R. S. 2020. Pengaruh kemampuan pemecahan masalah matematis mahasiswa Universitas Balikpapan melalui pendekatan metakognitif. Jurnal Math Educator Nusantara: Wahana Publikasi Karya Tulis Ilmiah Di Bidang Pendidikan Matematika 6(1), 13-21.

Yunita, D., and Wijayanti, A. 2017. Pengaruh media video pembelajaran terhadap hasil belajar IPA ditinjau dari keaktifan siswa. Sosiohumaniora: Jurnal Ilmiah Ilmu Sosial Dan Humaniora 3(2), 153-160. 